\title{
IDENTIFIKASI PENYAKIT MALARIA DENGAN PEMERIKSAAN SADT DI DESA TURUS KABUPATEN PURWOREJO
}

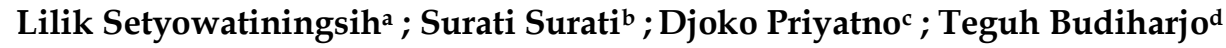 \\ $a, b, c, d$ Jurusan Analis Kesehatan ; Poltekkes Kemenkes semarang \\ Jalan Woltermonginsidi No.115; Pedurungan; Semarang
}

\begin{abstract}
Abstrak
Penyakit malaria ditularkan ke manusia melalui tusukan nyamuk Anopheles betina. Purworejo merupakan salah satu kabupaten endemis penyakit malaria di Jawa Tengah. Tujuan pengabdian masyarakat ini adalah melakukan pemeriksaan mikroskopis malaria menggunakan sediaan apus darah tepi (SADT) dan mengetahui kejadian malaria di Desa Turus Kabupaten Purworejo. Metode pengabdian masyarakat ini yaitu dengan survey maupun observasi kemudian melakukan pengambilan data dengan pemeriksaan sampel darah responden. Hasil identifikasi pemeriksaan mikroskopis malaria dengan metode SADT pada kegiatan pengabdian masyarakat di Desa Turus Kecamatan Kemiri Kabupaten Purworejo menunjukkan bahwa seluruh responden sejumlah 150 orang $(100 \%)$ dinyatakan negatif penyakit malaria. Kesimpulan kegiatan ini seluruh responden tidak terinfeksi malaria sehingga untuk kegiatan selanjutnya disarankan untuk melakukan pemeriksaan malaria secara imunoserologi untuk mengetahui adanya antibodi atau antigen spesifik malaria dalam tubuh responden
\end{abstract}

Kata kunci : Malaria, SADT, Kabupaten Purworejo

\begin{abstract}
[Identification of Malaria Disease Using SADT Method in Turus Village Purworejo Regency] Malaria diseases is transmitted to humans by pricking female Anopheles mosquitoes. Purworejo is one of the endemic districts for malaria in Central Java. The purpose of this community service activity is to conduct a microscopic examination of malaria using a peripheral blood smear (SADT) and to find out the incidence of malaria in Turus Village, Purworejo Regency. The method in this community service activity is by surveying and observation then collecting data by examining the respondent's blood sample. The results of identification of malaria microscopic examination using the SADT method in community service activities carried out in Turus Village, Kemiri District, Purworejo Regency, showed that all 150 respondents $(100 \%)$ tested negative for malaria. The conclusion of this activity is that all respondents are not infected with malaria so that for further activities it is recommended to carry out immunoserological malaria checks to determine the presence of malaria specific antibodies or antigens in the respondent's body.
\end{abstract}

Keywords: Malaria, SADT, Purworejo Regency

\section{Pendahuluan}

Malaria merupakan penyakit endemik yang ditularkan oleh nyamuk Anopheles. Penyebaran penyakit malaria sering terjadi pada daerah tropis, termasuk Indonesia (Prahutama \& Hoyyi,

*) Correspondence Author (Lilik Setyowatiningsih)

E-mail: liliksetyowati70@gmail.com
2016). Penyakit ini dapat menyebabkan resiko kematian terutama pada kelompok resiko tinggi yaitu bayi, anak balita dan ibu hamil. Malaria juga berdampak pada penurunan produktifitas kerja akibat anemia. (Kemenkes RI, 2011). Malaria adalah penyakit menular yang disebabkan oleh Plasmodium. Malaria ditularkan melalui gigitan nyamuk Anopheles betina yang mengandung 
Plasmodium didalamnya(Kemenkes RI, 2016). Terdapat lima spesies Plasmodium yaitu Plasmodium falciparum, Plasmodium vivax, Plasmodium ovale, Plasmodium malariae, dan Plasmodium knowlesi (Supranelfy, Warni, Inzana, \& Suryaningtyas, 2018).Suhu udara dan kelembaban lingkungan sekitar mempengaruhi perilaku nyamuk Anopheles. Hospes nyamuk Anopheles aktif pada senja hingga pagi hari dalam menghisap darah. Jarak terbangnya antara 0,5-3 $\mathrm{km}$, namun dipengaruhi juga oleh transportasi seperti kendaraan bermotor, kereta api, dan kapal serta angin di mana nyamuk berada(Sugiarti, Wahyudo, Kurniawan, \& Suwandi, 2020). Pemeriksaan parasit malaria adalah pemeriksaan darah penderita yang diduga malaria, baik secara mikroskopis dengan menggunakan sediaan apus darah tepi (SADT) maupun tes cepat menggunakan rapid diagnostik test (RDT). Penderita dinyatakan positif malaria apabila didalam pemeriksaan mikroskopis ditemukan Plasmodium sp dalam darahnya(Kementerian Kesehatan, Dirjen P2PL, 2017).

Purworejo merupakan salah satu daerah endemis malaria di Jawa Tengah dengan jumlah 728 kasus malaria pada tahun 2013 dan meningkat menjadi 803 kasus pada tahun 2014 (Dinas Kesehatan Kabupaten Purworejo, 2015). Pada tahun 2014 terjadi peningkatan kasus malaria di Desa Sokoagung Kecamatan Bagelen Kabupaten Purworejo (Sholichah, W, \& Ustiawan, 2015). Kasus malaria di Puskesmas Winong, Kecamatan Kemiri, Kabupaten Purworejo pada tahun 2006 sebesar 0,66 permil dengan jumlah 13 kasus dan hingga tahun 2015 tidak ada kasus. Tahun 2016 malaria muncul kembali dengan API sebesar 2,3 permil dengan jumlah 44 kasus dari hasil pemeriksaan sediaan darah mikroskopis. Kejadian malaria berada di empat desa yaitu Girijoyo, Turus, Girimulyo dan Winong. Kasus malaria paling banyak di Desa Turus dengan jumlah kasus 17 kasus sedangkan yang paling sedikit terdapat di Desa Winong yaitu 1 kasus (Nababan \& Umniyati, 2018). Menurut (Pramestuti, Ustiawan, \& Trisnawati, 2015), harus segera dilakukan investigasi pada waktu tersebut untuk mengetahui potensi penularan vektor malaria.

Tujuan pengabdian masyarakat ini yaitu melakukan pemeriksaan mikroskopis malaria dengan metode Sediaan Apusan Darah Tepi dan mengetahui kejadian malaria di Desa Turus Kecamatan Kemiri Kabupaten Purworejo. Manfaat pengabdian masyarakat ini yaitu Melakukan pemeriksaan dan penyuluhan malaria pada warga masyarakat Desa Turus
Kecamatan Kemiri Kabupaten Purworejo, dan melakukan kegiatan Tri Dharma Perguruan Tinggi di Lingkungan Poltekkes Kemenkes Semarang.

\section{Metode}

Kegiatan pengabdian masyarakat ini dilakukan dengan metode survey maupun observasi dan wawancara langsung dengan masyarakat Desa Turus Kabupaten Purworejo dilanjutkan dengan pengambilan sampel darah untuk pemeriksaan laboratorium. Sampel untuk identifikasi malaria menggunakan darah kapiler sejumlah 150 orang yang kemudian dilakukan pembuatan sediaan apus darah tebal dan tipis. Alat yang digunakan untuk pengambilan darah yaitu lancet, kapas alkohol swab, obyek glass dan Mikroskop. Reagen yang digunakan yaitu Giemsa dan Etanol.

\section{Hasil dan Pembahasan}

Hasil kegiatan Pengabdian Masyarakat pada warga masyarakat Desa Turus Kecamatan Kemiri Kabupaten Purworejo adalah seluruh responden sejumlah 150 orang $(100 \%)$ bersedia menjadi responden kegiatan pengabdian masyarakat. Berdasarkan hasil pemeriksaan laboratorium menunjukkan bahwa seluruh responden sejumlah 150 orang $(100 \%)$ tidak teridentifikasi penyakit malaria. Hasil ini sejalan dengan hasil penelitian Puasa (2018) yang menyatakan bahwa tidak ditemukan malaria positif pada masyarakat Desa Bringin Jaya Kecamatan Oba Tengah Kota Tidore (Puasa, H, \& Kader, 2018).

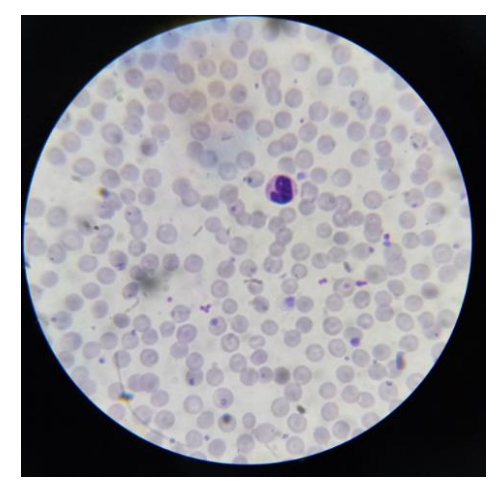

Gambar 1. Identifikasi malaria SADT tipis (hasil negatif) 


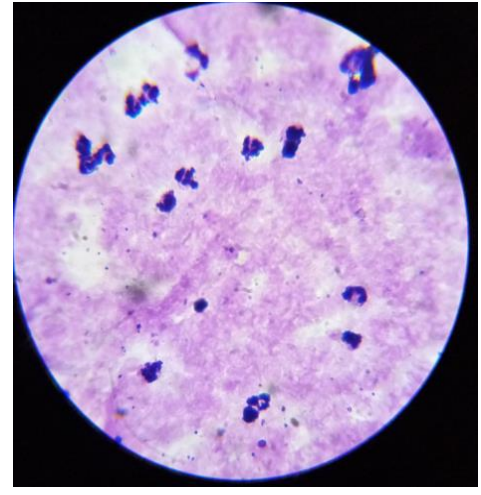

Gambar 2. Identifikasi malaria SAD T tebal (hasil negatif)

Hal ini karena pemerintah Kabupaten Purworejo sudah melakukan program eliminasi malaria dengan cara membentuk Juru Malaria Desa (JMD) pada setiap Puskesmas yang bertugas memantau dan melakukan pemeriksaan malaria gratis bagi masyarakat lokal maupun pendatang yang dicurigai menderita malaria dan melaporkan setiap kasus kepada Dinas Kesehatan Kabupaten Purworejo. Program ini sangat efektif untuk mengeliminasi prevalensi malaria di Kabupaten Purworejo. Sebelumnya diketahui bahwa banyaknya kasus Malaria di Kabupaten Purworejo disebabkan kasus malaria import yang dibawa oleh pendatang atau transmigran yang datang atau pulang ke Purworejo.

Tindak lanjut yang dilakukan oleh pengabdi adalah membagikan stikers osialisasi pencegahan dan penanggulangan malaria kepada masyarakat Desa Turus Kecamatan Kemiri Kabupaten Purworejo yang berisi tentang himbauan pemeriksaan malaria gratis ke fasilitas layanan kesehatan setempat bagi warga pendatang yang dimungkinkan membawa penyakit Malaria dari daerah asalnya. Pengabdi juga memberikan Banner ke Kantor Layanan Desa (Kelurahan) yang berisi tentang sosialisasi eliminasi malaria dan pemeriksaan malaria gratis bagi warga pendatang di Kabupaten Purworejo karena Kelurahan merupakan ruang publik yang strategis untuk pelayanan masyarakat umum.

Keterbatasan kegiatan pengabdian masyarakat ini yaitu pengambilan sampel dilakukan kepada warga masyarakat yang tidak menunjukkan gejala klinis penyakit malaria sehingga identifikasi malaria pada pemeriksaan mikroskopis sediaan darah tidak dapat mendeteksi adanya infeksi parasit malaria dengan kepadatan parasit yang rendah.

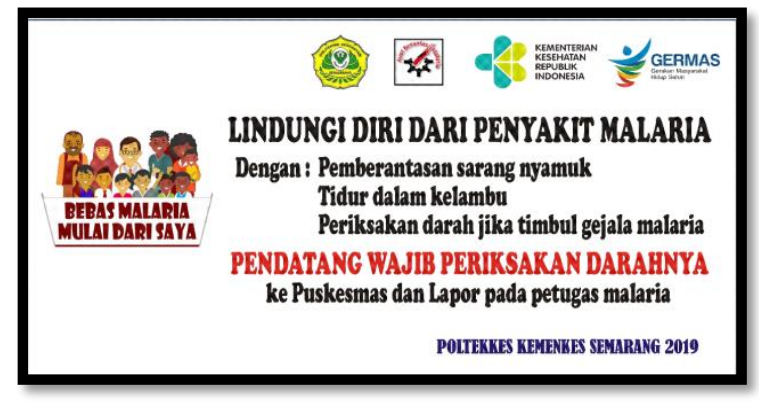

Gambar 3. Stiker tindak lanjut pengabmas

\section{Simpulan dan Saran}

Kesimpulan kegiatan pengabdian masyarakat ini yaitu berdasarkan hasil identifikasi laboratorium dengan pemeriksaan mikroskopis malaria menggunakan metode SADT dinyatakan bahwa seluruh responden sejumlah 150 orang $(100 \%)$ tidak terindikasi penyakit malaria. Saran pada kegiatan pengabdian masyarakat selanjutnya yaitu melakukan pemeriksaan malaria pada warga masyarakat di desa-desa yang belum terjangkau fasilitas layanan kesehatan serta melakukan pemeriksaan malaria secara imunoserologi dengan menggunakan metode rapid test untuk mengetahui adanya ikatan antara antibodi dan antigen pada tubuh responden.

\section{Ucapan Terima Kasih}

Ucapan banyak terima kasih disampaikan atas kesempatan yang diberikan untuk mendapatkan Dana Risbinakes DIPA Politeknik Kesehatan Kementerian Kesehatan Semarang, sehingga pengabmas ini dapat terselesaikan.

\section{Referensi}

Dinas Kesehatan Kabupaten Purworejo. (2015). Profil Kesehatan 2014 Menuju Purworejo Sehat. Retrieved from http://www.depkes.go.id/resources/dow nload/profil/PROFIL_KAB_KOTA_2014/3 306_Jateng_Kab_Purworejo_2014.pdf

Kemenkes RI. (2016). InfoDatin-Malaria-2016.pdf (pp. 1-7). pp. 1-7.

Kementerian Kesehatan, Dirjen P2PL, S. M. (2017). Pedoman Teknis Pemeriksaan Malaria. In Buku Pedoman. Retrieved from www.pppl.depkes.go.id/

Nababan, R., \& Umniyati, S. R. (2018). Analisis Spasial Kejadian Malaria Dan Habitat Larva Nyamuk Anopheles spp di Wilayah Kerja Puskesmas Winong Kabupaten Purworejo. Berita Kedokteran Masyarakat, 34(1), 11. 
https://doi.org/10.22146/bkm.26941

Prahutama, A., \& Hoyyi, A. (2016). Spatial Patern Penyebaran Malaria Di Jawa Tengah. Statistika, 4(2).

Pramestuti, N., Ustiawan, A., \& Trisnawati, U. F. (2015). Potensi Penularan Malaria di Desa Sigeblog , Kecamatan Banjarmangu , Kabupaten Banjarnegara. Balaba, 11(2), 6772.

Puasa, R., H, A. A., \& Kader, A. (2018). Identifikasi Plasmodium Malaria Didesa Beringin Jaya Kecamatan Oba Tengah Kota Tidore Kepulauan. Jurnal Riset Kesehatan, 7(1), 21. https://doi.org/10.31983/jrk.v7i1.3056

Sholichah, Z., W, B. F., \& Ustiawan, A. (2015). Malaria di Desa Sokoagung, Kecamatan Bagelen, Kabupaten Purworejo:
Karakteristik Dan Faktor Risiko. Balaba, 11(01), 51-58.

Sugiarti, S., Wahyudo, R., Kurniawan, B., \& Suwandi, J. F. (2020). The Physical, Chemical, and Biological Characteristics of Anopheles sp . a Potential Breeding Place in Puskesmas Hanura Working Area. Medula, 10(2), 272-277.

Supranelfy, Y., Warni, S. E., Inzana, N., \& Suryaningtyas, N. H. (2018). Penemuan Kasus Malaria Berdasarkan Pemeriksaan Mikroskopis di Kota Lubuklinggau dan Kabupaten Musi Rawas. ASPIRATOR Journal of Vector-Borne Disease Studies, 10(1), 27-36.

https://doi.org/10.22435/asp.v10i1.15 